University of Nebraska - Lincoln

DigitalCommons@University of Nebraska - Lincoln

\title{
Wheat Grain and Forage Yields are Affected by Planting and Harvest Dates in the Central Great Plains
}

Drew J. Lyon

University of Nebraska-Lincoln, drew.lyon@wsu.edu

David D. Baltensperger

University of Nebraska-Lincoln, dbaltensperger@tamu.edu

Melicio Siles

University of Nebraska-Lincoln

Follow this and additional works at: https://digitalcommons.unl.edu/panhandleresext

Part of the Agriculture Commons

Lyon, Drew J.; Baltensperger, David D.; and Siles, Melicio, "Wheat Grain and Forage Yields are Affected by Planting and Harvest Dates in the Central Great Plains" (2001). Panhandle Research and Extension Center. 13.

https://digitalcommons.unl.edu/panhandleresext/13

This Article is brought to you for free and open access by the Agricultural Research Division of IANR at DigitalCommons@University of Nebraska - Lincoln. It has been accepted for inclusion in Panhandle Research and Extension Center by an authorized administrator of DigitalCommons@University of Nebraska - Lincoln. 


\title{
Wheat Grain and Forage Yields are Affected by Planting and Harvest Dates in the Central Great Plains
}

\author{
Drew J. Lyon,* David D. Baltensperger, and Melicio Siles
}

\begin{abstract}
Although grazing of winter wheat (Triticum aestivum L.) is a common practice in the southern Great Plains, little is known about the efficacy of wheat as a dual-purpose crop in the Nebraska Panhandle. The objective of this study was to evaluate the effects of establishment and harvest times on forage and grain production of wheat cultivars adapted to the region. Six cultivars were planted at four dates (very early, recommended early, recommended late, and very late) in each of 3 yr. Forage samples were taken from a previously nonharvested area late in the fall, at jointing, and at the boot stage. Grain yield at maturity was measured from each forage harvest treatment and from a full-season unharvested control. In 2 of $3 \mathrm{yr}$, grain yield was reduced an average of $25 \%$ compared with the full-season check when plants were harvested for forage at the joint stage. No grain was produced when forage was removed at the boot stage. Forage removal during the fall averaged $1300 \mathrm{~kg} \mathrm{ha}^{-1}$ dry matter and resulted in insignificant losses in grain yield. While most of the fall growth was too low to the ground for clipping, it could provide highvalue supplemental grazing on account of the high crude protein $(310 \mathrm{~g}$ $\left.\mathrm{kg}^{-1}\right)$ and in vitro organic matter digestibility $\left(800 \mathrm{~g} \mathrm{~kg}^{-1}\right)$ levels. Spring grazing in this region is limited to the time prior to jointing if market conditions favor grain production.
\end{abstract}

$\mathrm{W}$ INTER WHEAT PASTURE PROVIDES high-quality forage for grazing livestock (Horn, 1984). The forage is high in moisture and soluble constituents during fall and winter and may be unable to meet the daily dry matter (DM) intake requirements of cattle (Bos taurus L.). At that time, crude protein concentration of wheat is high, sometimes exceeding $30 \%$ of DM, and fiber concentration is low. In the spring, yield and nutrient levels of wheat forage are greatly influenced by plant maturity, with crude protein concentration decreasing and fiber concentration increasing with maturation (Bolsen, 1984).

Numerous studies have investigated the effects of wheat grazing on grain yield (Redmon et al., 1995). Although the effects of environment, wheat physiology, grazing management, and compensation of grain yield components make it difficult to draw a uniform conclusion for the effects of grazing on grain yield, some general trends are evident.

Grazing tall winter wheat cultivars prior to culm elongation is likely to produce slight increases in grain yield relative to nongrazed wheat because of reduced lodging potential. In semi-dwarf cultivars, grazing is more likely to reduce grain yield. Semi-dwarf wheat cultivars require maximum photosynthetic tissue to produce maximum grain yield (Redmon et al., 1995). For semidwarf

Panhandle Research and Extension Center, 4502 Ave. I, Scottsbluff, NE 69361. Journal Series No. 12864 of the University of Nebraska Agricultural Research Division. Received 3 Dec. 1999. *Corresponding author (DLYON1@unl.edu).

Published in Crop Sci. 41:488-492 (2001) cultivars, net return is maximized when grazing is terminated at first hollow stem-the stage at which hollow stem can first be identified above the crown (Redmon et al., 1996). However, beyond an optimum leaf area index, excess foliage does not contribute to increased grain yield in taller wheat cultivars (Redmon et al., 1995).

Differences in fall forage yield among winter wheat cultivars has been reported as being sufficiently large to be of importance to wheat-stocker cattle producers (Krenzer et al., 1992). Unfortunately, selecting a winter wheat cultivar on the basis of forage or grain yield alone seldom results in the greatest economic return because higher grain yielding cultivars are not always among the highest forage yielding cultivars (Krenzer et al., 1996).

Winter wheat often is planted early to maximize fall forage production. Several problems can arise because of early planting. Semidwarf cultivars, with short coleoptile lengths, may have emergence problems because of the deeper planting depth required to place seed in adequate soil moisture during late-summer (Redmon et al., 1995). Early planting also shifts the period of major soil water extraction from spring to fall (Winter and Musick, 1993). This can reduce grain yields compared with wheat planted near the optimum date. Early planting of winter wheat also predisposes plants to infection by diseases such as root and crown rot [caused by the fungi Bipolaris sorokiniana (Sacc. In Sorok.) Shoem. and Fusarium spp.] (Fenster et al., 1972).

The great majority of research conducted on winter wheat grazing in the USA has been conducted in the southern Great Plains (Redmon et al., 1995). The potential for winter wheat to be used as a dual-purpose crop in western Nebraska has not been evaluated. Nebraska producers currently provide fall and spring forage by deferred grazing of summer pastures, purchased energy and protein supplements, and stored hay and haylage. Wheat hay and pasture could provide valuable fall and early spring supplementation for cow-calf operations in the central Great Plains, where the quantity and quality of pastures at these times are poor. The objective of this study was to evaluate the potential for winter wheat to be used for supplemental forage and grain production in the central Great Plains. Specifically, planting dates, forage harvest times, and cultivars were compared to determine forage yield and quality attributes relative to grain yield performance.

\section{MATERIALS AND METHODS}

Field studies were conducted at the University of Nebraska High Plains Agricultural Laboratory near Sidney, NE, at an

Abbreviations: ADF, acid detergent fiber; DM, dry matter; IVOMD, in vitro organic matter digestibility; NDF, neutral detergent fiber. 
elevation of $1315 \mathrm{~m}$ above sea level. Soils were an Alliance silt loam (fine-silty, mixed, superactive, mesic Aridic Argiustoll) in 1992-1993, a Goshen silt loam (fine-silty, mixed, superactive, mesic Pachic Argiustoll) in 1993-1994, and a Duroc loam (fine-silty, mixed, mesic Pachic Haplustoll) in 1994-1995. Nitrogen and phosphorus fertilization was based on University of Nebraska recommendations for a grain yield goal of 3200 $\mathrm{kg} \mathrm{ha}^{-1}$.

Six hard red winter wheat cultivars were seeded at a rate of $50 \mathrm{~kg} \mathrm{ha}^{-1}$ at four different dates-very early (23-28 August), recommended early (3-9 September), recommended late (10-19 September), and very late (21-30 September). Standard-height cultivars were Centura, Longhorn, Scout 66, and Siouxland. Semidwarf cultivars were Arapahoe and Vista. Longhorn has been marketed regionally as a dual-purpose wheat, for grain production and grazing, because it is semiawnless.

Planting dates and cultivars were arranged factorially within a randomized complete block design with four replications. Plot size was 1.8 by $7.3 \mathrm{~m}$ in $1992-1993$, and 1.8 by $9.1 \mathrm{~m}$ in the two subsequent years.

Forage samples were taken from previously unharvested $1-\mathrm{m}^{2}$ subplots in the fall, at early jointing, and at the boot stage. Jointing was defined as beginning when the first internode was visible. The last leaf was fully extended at the boot stage, but the head was not yet visible. All six cultivars from each planting date were harvested for forage at the same time, so not all cultivars were at the same developmental stage when harvested. However, all cultivars entered the early jointing and boot stages within one week of each other. Plants were clipped at the soil surface and oven-dried at $43^{\circ} \mathrm{C}$ to constant dry weight. A representative subsample was taken from each subplot, milled with a Wiley shear-mill (A.H. Thomas, Philadelphia, PA) using a $0.5-\mathrm{cm}$-diam round screen, and stored in plastic bags for quality analysis at the completion of the field study. At maturity, grain and forage were measured from each previously harvested subplot and from an additional subplot previously unharvested, which was designated as the control.

Crude protein, acid detergent fiber (ADF), neutral detergent fiber (NDF), and in vitro organic matter digestibility (IVOMD) were determined with a near-infrared reflectance spectrophotometer (Technicon Infralyzer 500, Bran \& Luebbe Analyzing Technologies, Buffalo Grove, IL) over a wavelength range of 1100 to $2500 \mathrm{~nm}$ with 2-nm steps. Wet analysis data from approximately 100 samples were used in developing and verifying near-infrared reflectance spectrophotometer prediction equations. Samples used for verification were not used in developing prediction equations. As much as possible, wet lab samples originated from different years, blocks, planting dates, cultivars, and harvest dates.

Wet analysis procedures were as follows: crude protein was determined by the generic combustion method described by Sweeney (1989); ADF by procedures described in AOAC, 1990; NDF by the Mertens (1992) modification of Goering and Van Soest (1970); and IVOMD by the method described by Tilley and Terry (1963). Wheat growth, especially in the fall, was prostrate and difficult to sample without some soil contamination; therefore, the percentage of ash in each sample was determined by combustion (AOAC, 1990) and used to adjust the quality variables to an organic matter basis.

To determine the effect of planting date on root and crown rot, plants from Arapahoe and Longhorn were evaluated. In the spring of each year, shortly after resumption of growth, samples of 10 plants were removed from all plots seeded to these two cultivars. Soil was washed from the roots with water and visual crown and root rot ratings made on a scale of 0 to
5 , with 0 representing a healthy plant having no visible crown or root lesions and 5 being a dead plant.

Analysis of variance was performed using the mixed model procedure of SAS and including terms for year, planting date, harvest time, and cultivar. Results from individual years were analyzed and presented separately on account of significant year by treatment interactions. Means separation was performed by Fisher's protected LSD at $\alpha=0.05$.

\section{RESULTS}

The central Great Plains has a highly variable climate, and the growing seasons in this study were no exception. The 1992-1993 season was characterized by a colder than normal fall and winter with above average snowfall (Fig. 1). The first snowfall came in late October and the ground remained covered with snow until March. Consequently, there was no fall forage harvest in 1992. Spring precipitation in 1993 was near normal, with the exception of a drier than normal May. On June 12, 1993 a hail storm resulted in significant grain yield loss.

The 1993-1994 season began with a wetter and cooler than normal fall, followed by a drier and warmer than normal spring (Fig. 1). Abundant precipitation at the end of May and early June preserved average grain yields in 1994. Above-average spring precipitation, including a much wetter than normal May, resulted in grain and forage yields substantially greater than normal in 1995.

\section{Grain Yield}

Wheat harvested for forage in the boot stage did not produce grain in any year, and therefore, this harvest stage was not included in the analysis of variance for grain yield. There was a significant $(P<0.05)$ planting date $\times$ harvest date interaction in 1993, but the range in grain yields was small enough that the interaction was of no practical significance.

In 1993, when averaged across all planting dates, forage removal at jointing resulted in no grain yield difference compared with the control treatment (Table 1). Grain yields for both the full-season control and jointharvested forage treatments increased as planting date was delayed in 1993. Grain yields in 1993 were significantly reduced by the 12 June 1993 hail storm.

Grain yield in 1994 increased as planting date was delayed from the very early planting date to the recommended late planting date (Table 1). Averaged across forage harvest dates, wheat planted on the very late planting date yielded $12 \%$ less grain than wheat planted on the recommended late date. Averaged across planting dates, grain yield was reduced compared with the full-season control when wheat was harvested for forage at jointing, but not when harvested in the fall. In 1995, as in the previous $2 \mathrm{yr}$, grain yield increased as planting date was delayed (Table 1). As in 1994, grain yield in 1995 was reduced compared with the full-season control when wheat plants were harvested for forage at the joint stage.

Crown and root rot ratings taken in early spring each year identified a decrease $(P<0.05)$ in the levels of this disease as planting date was delayed in 1993 and 

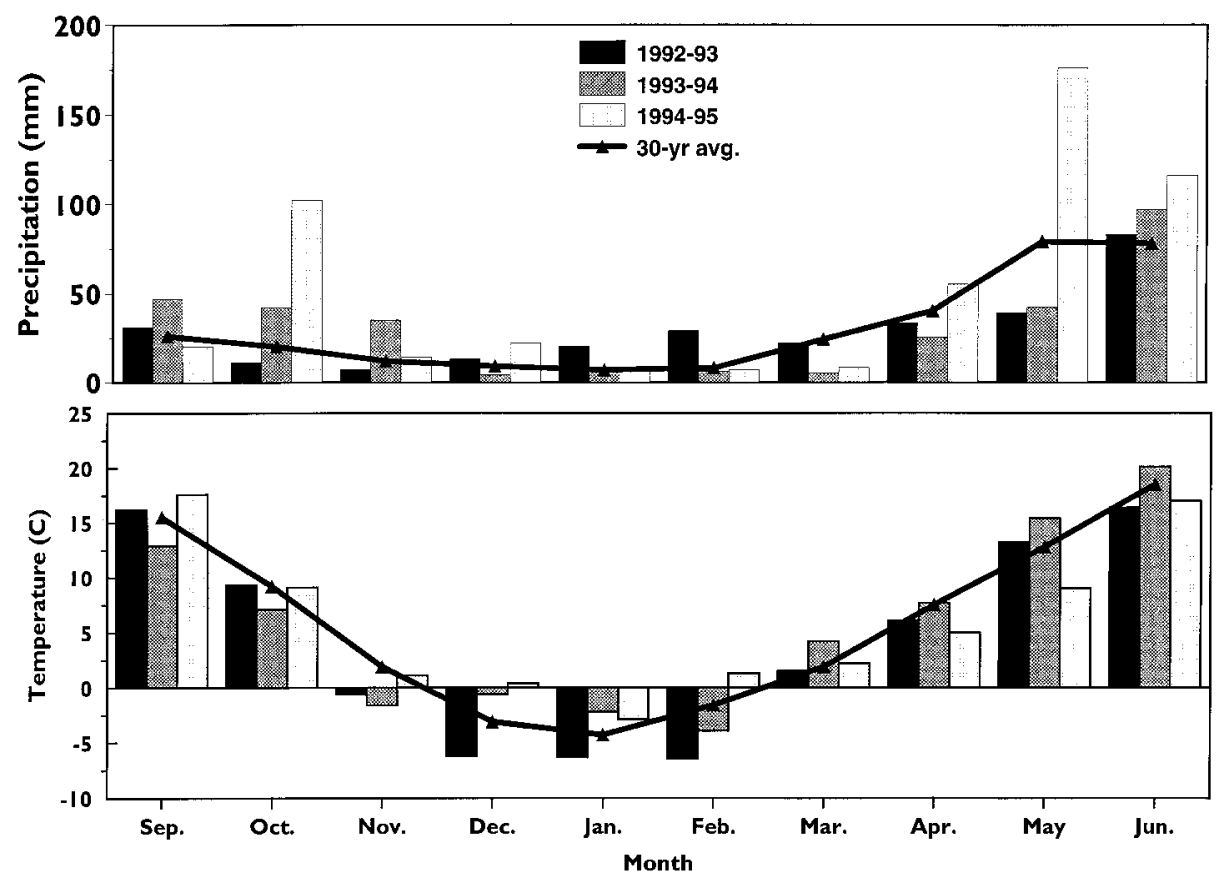

Fig. 1. Monthly average precipitation and temperature during the wheat growing season at Sidney, NE, from 1992 through 1995.

1994 (data not shown). This relationship agrees with previous reports that early planted wheat is more susceptible to disease and insect damage than later planted wheat (Fenster et al., 1972; Cook and Veseth, 1991). Planting date, however, did not influence the incidence of crown and root rot in 1995 .

\section{Forage Yield}

In 1992, fall forage was not collected because of a late October snowstorm and subsequent cold temperatures that prevented snow melt. While not a common occurrence, growers in the central Great Plains can expect to harvest little or no fall forage in about 3 out of every

Table 1. Grain yields for wheat planted at four different dates in the fall and harvested for forage in the late fall, at jointing, and at maturity at Sidney, NE.

\begin{tabular}{|c|c|c|c|c|c|c|}
\hline \multirow[b]{2}{*}{$\begin{array}{l}\text { Harvest date } \\
\text { (HD) }\end{array}$} & \multicolumn{4}{|c|}{ Planting date (PD) } & \multirow[b]{2}{*}{$\begin{array}{l}\text { HD } \\
\text { mean }\end{array}$} & \multirow[b]{2}{*}{ LSD 0.05} \\
\hline & $\begin{array}{l}\text { Very } \\
\text { early }\end{array}$ & $\begin{array}{l}\text { Rec. } \\
\text { early }\end{array}$ & $\begin{array}{l}\text { Rec. } \\
\text { late }\end{array}$ & $\begin{array}{l}\text { Very } \\
\text { late }\end{array}$ & & \\
\hline & & & $\mathbf{g g ~ h a}$ & & . & \\
\hline Fall & 587 & 685 & $\begin{array}{c}3 \text { harv } \\
607\end{array}$ & 942 & 705 & 166 \\
\hline Joint stage & 460 & 552 & 732 & 1040 & 696 & 166 \\
\hline Full-season & 587 & 685 & 607 & 942 & 705 & 166 \\
\hline PD mean & 545 & 641 & 649 & 975 & 702 & 143 \\
\hline LSD 0.05 & NS & 129 & NS & NS & NS & \\
\hline Fall & 2040 & 2870 & 3130 & 2570 & 2650 & 299 \\
\hline Joint stage & 1560 & 2360 & 2670 & 2350 & 2350 & 299 \\
\hline Full-season & 2230 & 2910 & 3240 & 3050 & 2860 & 299 \\
\hline PD mean & 1940 & 2710 & 3020 & 2660 & 2580 & 180 \\
\hline LSD 0.05 & 296 & 296 & 296 & 296 & 148 & \\
\hline Fall & 3800 & 4070 & 4890 & 4600 & 4340 & 571 \\
\hline Joint stage & 2430 & 2920 & 3600 & 3800 & 3190 & 571 \\
\hline Full-season & 4030 & 4090 & 4950 & 4550 & 4400 & 571 \\
\hline PD mean & 3420 & 3690 & 4480 & 4320 & 3980 & 387 \\
\hline LSD 0.05 & 526 & 526 & 526 & 526 & 263 & \\
\hline
\end{tabular}

NS $=$ not significantly different at $\alpha=0.05$.
$10 \mathrm{yr}$ because of inclement winter weather. Cutting at the boot stage provided the greatest forage yield in 1993 (Table 2). This was due to the June hail storm that reduced forage yield at grain harvest time. Forage yield at the joint stage tended to be reduced by later planting, whereas yield tended to be greater with delayed planting at the boot stage and at maturity.

In 1994, above-normal fall precipitation (Fig. 1) resulted in excellent fall forage yields. For the earliest planting date, fall forage yield exceeded or matched forage yields collected at the joint or boot stages, respectively (Table 2). At the three later planting dates, fall forage yields equaled those collected at the joint stage. Forage yields in the fall and at the joint stage declined with later planting, while delayed planting tended to increase yield, or have little effect on yield, at the boot stage or at maturity.

In 1995, above-normal spring precipitation resulted in large differences in forage yields among the different spring cutting times (Table 2 ). Forage yields at maturity were at least $5000 \mathrm{~kg} \mathrm{ha}^{-1}$ greater than at the boot stage, and boot stage yields were about $3000 \mathrm{~kg} \mathrm{ha}^{-1}$ greater than at the joint stage. Fall forage yields were the least of all the harvest dates. As in 1994, forage yields at the fall and joint stages declined with later planting; however, unlike 1993 and 1994, yield at the boot stage declined at the latest planting date (Table 2). No clear trend with planting date was observed for forage yield harvested at maturity.

\section{Forage Quality}

Winter wheat forage is an excellent protein and energy source for cattle. Crude protein levels in 1994 and 1995 always exceeded $200 \mathrm{~g} \mathrm{~kg}^{-1}$ when forage was harvested in either the fall or at the joint stage (Table 3 ). The average crude protein concentration for these $2 \mathrm{yr}$ 
Table 2. Forage yields for wheat planted at four different dates in the fall and harvested for forage in the late fall, at jointing and boot stages of plant development, and at maturity at Sidney, NE.

\begin{tabular}{|c|c|c|c|c|c|c|}
\hline \multirow[b]{2}{*}{$\begin{array}{l}\text { Harvest date } \\
\text { (HD) }\end{array}$} & \multicolumn{4}{|c|}{ Planting date (PD) } & \multirow[b]{2}{*}{$\begin{array}{c}\text { HD } \\
\text { mean }\end{array}$} & \multirow[b]{2}{*}{ LSD 0.05} \\
\hline & $\begin{array}{l}\text { Very } \\
\text { early }\end{array}$ & $\begin{array}{l}\text { Rec. } \\
\text { early }\end{array}$ & $\begin{array}{l}\text { Rec. } \\
\text { late }\end{array}$ & $\begin{array}{l}\text { Very } \\
\text { late }\end{array}$ & & \\
\hline & 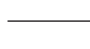 & 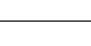 & dry matter & & - & \\
\hline Fall & - & - & 1993 harve & - & - & - \\
\hline Joint stage & 1500 & 1780 & 1470 & 960 & 1430 & 408 \\
\hline Boot stage & 4820 & 5150 & 5990 & 6380 & 5580 & 408 \\
\hline Full-season & 3340 & 3950 & 3500 & 4720 & 3880 & 583 \\
\hline PD mean & 3220 & 3630 & 3650 & 4020 & 3630 & 286 \\
\hline LSD 0.05 & 503 & 503 & 503 & 503 & 263 & \\
\hline & & & 1994 ilatve & & & \\
\hline Fall & 3200 & 1500 & 404 & 258 & 1340 & 577 \\
\hline Joint stage & 1620 & 1330 & 974 & 513 & 1110 & 577 \\
\hline Boot stage & 3220 & 3880 & 3710 & 3200 & 3500 & 577 \\
\hline Full-season & 5470 & 6650 & 7290 & 6700 & 6520 & 577 \\
\hline PD mean & 3380 & 3340 & 3090 & 2670 & 3120 & 288 \\
\hline LSD 0.05 & 577 & 577 & 577 & 577 & 288 & \\
\hline & & & & & & \\
\hline Fall & 2780 & 1750 & 520 & $\mathbf{0}$ & 1260 & 825 \\
\hline Joint stage & 4840 & 4600 & 3280 & 1450 & 3540 & 825 \\
\hline Boot stage & 8700 & 9410 & 8130 & 5200 & 7860 & 825 \\
\hline Full-season & 14800 & 14200 & 15900 & 13400 & 14600 & 953 \\
\hline PD mean & 7780 & 7500 & 6960 & 5010 & 6810 & 429 \\
\hline LSD 0.05 & 896 & 896 & 896 & 896 & 455 & \\
\hline
\end{tabular}

and harvest dates was $310 \mathrm{~g} \mathrm{~kg}^{-1}$. This compares to a 3 -yr crude protein average of $170 \mathrm{~g} \mathrm{~kg}^{-1}$ at the boot stage. In 1994, crude protein concentration was greatest at the joint stage, while in 1995 it was greatest in the fall. Crude protein levels were at their lowest when wheat was planted at the earliest date. Subsequent planting dates tended to have similar crude protein levels. In 1994, Siouxland had crude protein levels about $10 \%$ greater than the other cultivars, while in 1995 , Scout 66 and Longhorn had crude protein levels 6 to $9 \%$ lower than the other cultivars. The reason for these differences is not clear.

The IVOMD of wheat forage was, with few exceptions, greater than $800 \mathrm{~g} \mathrm{~kg}^{-1}$. This suggests that nutrient availability is excellent with wheat forage. While treatment differences were observed (data not shown), these differences were small enough, typically less than $5 \%$, to be of little practical significance. Forage harvested in the fall exhibited erratic IVOMD values. This may have been the result of subsampling error. Separate forage subsamples were used for IVOMD and ash analysis. This was most evident with fall samples, where soil contamination, as a percentage of the sample was greatest.

In 1994 and 1995, ADF and NDF values for fall harvested forage significantly increased as planting date was delayed (data not shown). Planting date did not influence ADF and NDF values for forage harvested in the spring. In 1994, ADF and NDF values were similar for forage harvested at the joint and boot stages (average $\mathrm{ADF}=370 \mathrm{~g} \mathrm{~kg}^{-1}$; average $\mathrm{NDF}=620 \mathrm{~g} \mathrm{~kg}^{-1}$ ). In 1995, ADF and NDF values were greater for forage harvested at the boot stage $\left(\mathrm{ADF}=390 \mathrm{~g} \mathrm{~kg}^{-1}\right.$; NDF $=$ $650 \mathrm{~g} \mathrm{~kg}^{-1}$ ) compared with forage harvested at the joint stage $\left(\mathrm{ADF}=260 \mathrm{~g} \mathrm{~kg}^{-1}\right.$; NDF $\left.=480 \mathrm{~g} \mathrm{~kg}^{-1}\right)$.

\section{DISCUSSION}

The cultivars used in this study represented a range of growth habits and maturities. While some differences among the cultivars were observed for various traits in specific years, there was no consistent or overall trend for superior forage performance by any of the cultivars over the $3 \mathrm{yr}$ of the study. Lower grain yields from Longhorn and Scout 66 were certainly not offset by an expected improvement in forage yield performance. Arapahoe, the most widely grown wheat in the region, appears to be well adapted as a dual-purpose wheat.

Forage removal during the fall resulted in very little loss in grain yield and provided an average of $1300 \mathrm{~kg}$ $\mathrm{ha}^{-1}$ of forage, with an average of $310 \mathrm{~g} \mathrm{~kg}^{-1}$ of crude protein. While this growth was too low to the ground for haying, it could provide high value supplemental grazing. Many wheat fields in the central Great Plains are adjacent to wheat stubble fields or pastures, which can supply adequate energy and dry matter, but are

Table 3. Crude protein for wheat planted at four different dates in the fall and harvested for forage in the late fall, at jointing and boot stages of plant development at Sidney, NE.

\begin{tabular}{|c|c|c|c|c|c|c|}
\hline \multirow[b]{2}{*}{$\begin{array}{l}\text { Harvest date } \\
\text { (HD) }\end{array}$} & \multicolumn{4}{|c|}{ Planting date (PD) } & \multirow[b]{2}{*}{$\begin{array}{l}\text { HD } \\
\text { mean }\end{array}$} & \multirow[b]{2}{*}{ LSD 0.05} \\
\hline & $\begin{array}{l}\text { Very } \\
\text { early }\end{array}$ & $\begin{array}{l}\text { Rec. } \\
\text { early }\end{array}$ & $\begin{array}{l}\text { Rec. } \\
\text { late }\end{array}$ & $\begin{array}{l}\text { Very } \\
\text { late }\end{array}$ & & \\
\hline & \multicolumn{5}{|c|}{$-\mathbf{g ~ k g}^{-1}$} & \\
\hline & & 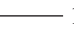 & 93 harv & - & - & \\
\hline Fall & - & - & - & - & - & - \\
\hline Joint stage & - & - & - & - & - & - \\
\hline Boot stage & 179 & 177 & 184 & 196 & 184 & 6.7 \\
\hline PD mean & - & - & - & - & - & - \\
\hline LSD 0.05 & - & - & - & - & - & \\
\hline Fall & 290 & 344 & 332 & 355 & 330 & 27.0 \\
\hline Joint stage & 331 & 390 & 394 & 391 & 376 & 27.0 \\
\hline Boot stage & 175 & 197 & 236 & 248 & 214 & 26.6 \\
\hline PD mean & 265 & 310 & 320 & 332 & 307 & 16.0 \\
\hline \multirow[t]{2}{*}{ LSD 0.05} & 27.1 & 26.7 & \multirow{2}{*}{\multicolumn{2}{|c|}{1995 harvest }} & 13.5 & \\
\hline & & & & & & \\
\hline Fall & 27 & 311 & 313 & - & 299 & 12.0 \\
\hline Joint stage & 201 & 216 & 262 & - & 226 & 12.0 \\
\hline Boot stage & 110 & 111 & 125 & - & 115 & 12.0 \\
\hline PD mean & 195 & 213 & 233 & - & 213 & 6.9 \\
\hline LSD 0.05 & 12.0 & 12.0 & 12.0 & - & 6.9 & \\
\hline
\end{tabular}


poor sources for protein. Wheat could be an excellent source of protein supplementation with limited loss of grain yield if grazing were terminated prior to jointing. The irregular availability of wheat forage due to snow cover would require backup supplemental feed for this to be effective.

In all years except 1993-the year of the June hail storm-grain yield was reduced compared with the fullseason control when plants were harvested for forage at the joint stage. Clipping plants at the soil surface at this stage probably resulted in greater removal of plant material than grazing, and this may have resulted in greater grain yield reductions than would have been observed with grazing. Additionally, plant clipping is likely to have biased our forage yields upward relative to grazable yields.

While the literature is inconsistent on the critical timing of grazing termination to prevent grain yield reduction (Redmon et al., 1995), most recommendations encourage animal removal prior to floral initiation or jointing. This study suggests that this may be even more critical in the central Great Plains, where wheat enters the reproductive stages of development during a period when lengthening days and rapidly increasing temperatures result in more rapid plant development than in the southern Great Plains.

Forage yields were consistently reduced for the first two harvest dates with delayed planting; however, grain yields were increased when planting was delayed through the recommended late date. This may have been due, at least in part, to a reduction in crown and root rot with later plantings. Crown and root rot ratings decreased as planting date was delayed in 2 of the $3 \mathrm{yr}$ of this study. In work conducted in western Nebraska during the 1950s and 1960s, Fenster et al. (1972) found significant reduction in the incidence and severity of crown and root rot when seeding dates were delayed from 20 August to 30 September.

The trade-off between early planting for early fall forage and decrease in grain yield would have to be evaluated by the producer on the basis of the value of grazing relative to grain yield. The 3 -yr average increase in fall forage for this study was $1500 \mathrm{~kg} \mathrm{ha}^{-1}$ when wheat was planted at the earliest planting date compared with the average of the three later planting dates. This includes one year, 1993, when no fall forage was harvested because of inclement winter weather. Given the high quality of fall wheat forage, early planting for increased fall grazing would allow a producer to take advantage of market conditions that favor beef production, by providing supplemental feed that alleviates protein and energy deficiencies in deferred summer pastures.

Forage harvest at the boot stage completely eliminated subsequent grain production. Therefore, to be cost effective, forage yield of 5 to $10 \mathrm{Mg} \mathrm{ha}^{-1}$ at the boot stage would have to be of equivalent or greater value than grain yield of 2 to $3 \mathrm{Mg} \mathrm{ha}^{-1}$.
Harvesting or grazing wheat also may reduce economic risk, especially in an environment such as the central Great Plains where hail and drought frequently reduce grain yield. For example, in 1993 grain yield averaged just $700 \mathrm{~kg} \mathrm{ha}^{-1}$ because of hail damage. Grazing or harvesting the wheat as forage prior to the hail storm would have provided economic value from the wheat that would not have been realized if grown only for grain. The use of the dual-purpose, forage-grain wheat production system as a means of managing economic risk in the central Great Plains requires a producer to be flexible in cattle management and marketing.

As evidenced by the many year $\times$ treatment interactions, choosing the appropriate use for wheat in any given year is difficult. However, in years where adequate fall and early spring forage are available, grazing or harvesting forage can reduce overall farm production risk and provide a high quality supplement to beef cattle, without seriously reducing subsequent grain yield. While the consistency of dual-purpose wheat production in this region may not be as great as in the southern Great Plains, current wheat cultivars have forage yield and quality characteristics that provide economic potential for wheat utilization as forage and grain.

\section{REFERENCES}

Association of Official Analytical Chemists. 1990. Official methods of analysis. 15th ed. AOAC, Arlington, VA.

Bolsen, K.K. 1984. Feeding value of wheat silage and hay as wheat crop alternatives. p. 55-64. In G.W. Horn (ed.) Proc. Natl. Wheat Pasture Symp. Okla. Agric. Exp. Stn. MP-115.

Cook, R. J., and R.J. Veseth. 1991. Wheat Health Management. American Phytopathological Society, St. Paul, MN.

Fenster, C.R., M.G. Boosalis, and J.L. Weihing. 1972. Date of planting studies of winter wheat and winter barley in relation to root and crown rot, grains yields and quality. University of Nebraska Research Bulletin 250.

Goering, H.K., and P.J. Van Soest. 1970. Forage fiber analysis: Apparatus, reagents, procedures, and some applications. USDA-ARS Agric. Handb. 379. U.S. Gov. Print. Office, Washington, DC.

Horn, F.P. 1984. Chemical composition of wheat pasture. p. 47-54. In G.W. Horn (ed.) Proc. Natl. Wheat Pasture Symp. Okla. Agric. Exp. Stn. MP-115.

Krenzer, E.G., Jr., A.R. Tarrant, D.J. Bernardo, and G.W. Horn. 1996. An economic evaluation of wheat cultivars based on grain and forage production. J. Prod. Agric. 9:66-73.

Krenzer, E.G., Jr., J.D. Thompson, and B.F. Carver. 1992. Partitioning of genotype $\times$ environment interactions of winter wheat forage yield. Crop Sci. 32:1143-1147.

Mertens, D.R. 1992. Critical conditions in determining detergent fiber. p. C1-C8. In Proc. NFTA Forage Analysis Workshop. Denver, CO.

Redmon, L.A., G.W. Horn, E.G. Krenzer, Jr., and D.J. Bernardo. 1995. A review of livestock grazing and wheat grain yield: Boom or bust? Agron. J. 87:137-147.

Redmon, L.A., E.G. Krenzer, Jr., D.J. Bernardo, and G.W. Horn. 1996. Effect of wheat morphological stage at grazing termination on economic return. Agron. J. 88:94-97.

Sweeney, R.A. 1989. Generic combustion method for determination of crude protein in feeds: Collaborative study. J. Assoc. Off. Anal. Chem. 72:770-774.

Tilley, J.M.A., and R.A. Terry. 1963. A two-stage technique for the in vitro digestion of forage crops. J. Brit. Grassland Soc. 18:104-111.

Winter, S.R., and J.T. Musick. 1993. Wheat planting date effects on soil water extraction and grain yield. Agron. J. 85:912-916. 